\title{
Regional Aspects of Forecasting the Economic Consequences of the Spread of the Coronavirus Pandemic in Sverdlovsk Oblast
}

\author{
Avdyukova A.E. ${ }^{1,2 *}$ Bocharnikova E.V. ${ }^{2}$ \\ ${ }^{1}$ Ural State Pedagogical University, Yekaterinburg, Russian Federation \\ ${ }^{2}$ Ural State University of Economics, Yekaterinburg, Russian Federation \\ *Corresponding author.Email: avdukova@bk.ru
}

\begin{abstract} influencing factors on the stabilization of export reduction.

regional economy

\section{INTRODUCTION}

During the global crisis caused by the new coronavirus pandemic (2019-nCoV), certain adjustments are being made to the development of foreign trade relations. In this regard, the government of the regions, which are faced with a difficult choice between restraining the spread of the coronavirus pandemic and the economic welfare on the territory, have a great responsibility for regulating the restrictions.

Representatives of various professional communities express their assumptions about the economic consequences of the spread of the pandemic. Some statements are subjective and overly generalized, while other assumptions and forecasts are based on objective statistics, research results, and previously identified patterns of economic development during periods of pandemics. Researchers are creating new systems and models for tracking the consequences of global crises, focusing on a variety of indicators and market segments. So, the school of digital economy of Far Eastern Federal University, developing a forecast model of the situation in
\end{abstract}

The article actualizes the problem of socio-economic consequences of the spread of the new coronavirus infection (2019-nCoV) for the regional economy. The authors emphasize the importance of foreign economic relations and foreign trade activities for the economy of Sverdlovsk Oblast. Analysis of scientific research has shown that these indicators are currently most susceptible to changes in different countries. The authors justify the tendency to stabilize the decline in exports and imports through reduced FTT (foreign trade turnover) indicators without further significant reduction, which is observed in Sverdlovsk Oblast due to the spread of the pandemic. The article presents an analysis of indicators based on which economic factors are described, causing a reasonable trend. The authors refer to the economic factors of stabilization reduction of exports and imports in Sverdlovsk Oblast: reduced purchasing power and the rate of import substitution chosen in a number of countries. Among the identified factors that provide a downward trend, the authors highlight the features of establishing and maintaining business contacts with business representatives from South Asian countries. The authors consider the competitiveness of regional products to be significantly

As a result of the study, it is concluded that taking into account positive and negative factors and further monitoring their impact, it is possible to significantly reduce socio-economic losses in the regional economy. Keywords: consequences of the spread of the pandemic, exports and imports, trends and factors of the

Russia after the end of the coronavirus pandemic, did not "take global economic indicators - GDP, GRP and similar ones, because they do not particularly affect the lives of ordinary citizens and are more interesting to economists rather than ordinary people". In their forecasts, the researchers focused on the indicators that are closest to the characteristics of the population's well-being [9].

"RBC Market research" together with SN PRO, conducted a survey on the consequences of the coronavirus for the Russian economy among business representatives, and concluded that "many enterprises were forced to close down, there was a reduction in aggregate demand and the share of the unemployed increased" [14].

Ceylan, R. F., Ozkan, B., Mulazimogullari, E. in their study noted the importance of public confidence in the state as a result of the impact of the pandemic. "Moral assistance to individuals and societies is also necessary for economic and social trust. Without confidence, none of the industry restrictions will be effective for economic recovery in terms of both demand and supply" [2].

As the study shows (Malliet, P.; Reynes, F.; Landa, G.; Hamdi-Cherif, M.; Saussay, A.), strict isolation measures introduced in France during the spread of the coronavirus have led not only to economic deterioration, but also to 
positive effects: improved environment due to a $6.6 \%$ reduction in $\mathrm{CO}(2)$ emissions in 2020; reduced imports of fossil energy stimulated investment in the country's energy efficiency[4].

It is difficult not to agree with E. V. Gnatyshina and T. V. Sidelnikova, who note the special significance of the world happiness index (WorldHappinessIndex) in the process of studying the well-being of the population, in which one of the main indicators is the environment. Reflecting the well-being of people in different countries of the world, this index was proposed at the UN General Assembly in July 2011 as a tool for sustainable development (SDSN) of the countries of the world [11].

The research team (Albu, L. L.; Preda, C. I. ; Lupu, R.; Dobrota, C. E.; Calin, G. M. ; Boghicevici) propose, first of all, "analyzing the dynamics of the spread of the epidemic among the population" [1].

According to Rastvortseva, S. N. and Snitko, L. T., in the context of the spread of the pandemic, the idea of finding "ways to meet existing needs at the expense of limited resources" is quickly becoming particularly relevant [7].

Phillipson, J., Gorton, M., Turner, R., Shucksmith, M., Aitken-McDermott, in the study of the spread of the consequences of the pandemic in Great Britain and the EU, assume that countries that are more or less dependent on exports and imported resources will find it very difficult to achieve the goal of maintaining the well-being of the population and achieving the goals of increasing exports and imports [6].

The economic impact of the pandemic of the coronavirus infection, as suggested by Singh, G; Dharampal; Jyoti, will be more serious for India due to displacing a large number of people below the poverty line, increasing social and economic inequality[8].

Erokhin, V. and Gao, T. M., having conducted research in 45 developing countries, focus on studying the well-being of the population during the spread of the coronavirus, which is identified with security at the national level and which, according to scientists, "increasingly depends on international exchange, foreign trade policy and macroeconomic parameters of the global food market" [3].

In this regard, alarming are the statements of the World Trade Organization (WTO) [13] that since the beginning of the pandemic, a number of countries (Vietnam, Kyrgyzstan, North Macedonia, Ukraine, Thailand and Egypt) have banned the export of various food and agricultural products. Russia has introduced temporary restrictions on wheat exports. The countries have also introduced stricter customs controls on cargo ships [15].

Petrunenko, I.; Podtserkovny, I., note that "States that depend on the export of natural resources and raw materials, faced with a crisis, are forced to sell them for nothing, so they will suffer great losses", which also in its turn affects the well-being of citizens[5].

Thus, the analysis of the results of research and scientific papers devoted to the study of the consequences of the pandemic has shown that the authors in their forecasts focus primarily on the economic well-being of the population associated with international economic relations, which are based on exports and imports.

\section{METHODS OF RESEARCH}

The methodology of this study correlates with the specifics of the situation of the socio-economic global crisis associated with the spread of the consequences of the coronavirus pandemic. The study was conducted on the basis of Ural State Pedagogical University and Ural State University of Economics USUE during 2020 and includes the ratio of quantitative and qualitative research data.

The methodology of this study was defined by the key concepts that make up the conceptual scheme of the study: trends, economic factors, forecast, foreign economic relations, export, import and includes: analysis of scientific and non-academic sources, statistics and dynamics of indicators that characterize the subject's foreign trade over the past 7 months, as well as factor analysis,

The main research questions are:

- In the context of the pandemic, what are the most significant economic factors affecting the region's economy?

- Are there any negative economic factors affecting the regional economy during the pandemic?

- Are there any economic factors that have a positive impact on the economy?

The purpose of the study is to determine the factors that affect the dynamics of exports and imports in the region and determine the trend that characterizes the foreign trade of Sverdlovsk Oblast in the near future.

\section{RESULTS OF THE STUDY}

The pandemic of the new coronavirus infection (2019$\mathrm{nCoV}$ ) makes certain adjustments to the development of foreign trade relations (FTR) in Sverdlovsk Oblast. The importance of foreign economic relations and foreign trade activities of Sverdlovsk Oblast has been updated since the early 90's and it was due to the need to meet the needs of the socio-economic complex against the background of a deep economic crisis. This explains the key role of foreign trade in the long-term economic strategy of the regional government, aimed primarily at improving the standard of living of citizens and enhancing their well-being [10].

The dynamics of indicators that characterize the subject's foreign trade over the past 7 months is presented in table 1. 
Table 1 Indicators of foreign trade of Sverdlovsk Oblast, thousand US dollars

\begin{tabular}{|c|c|c|c|c|c|c|}
\hline Indicator & Oct.2019 & Nov. 2019 & Dec.2019 & Jan. 2020 & Feb.2020 & March 2020 \\
\hline FTT & \multicolumn{3}{|c|}{$\begin{array}{c}3737902,32 \\
(106.54 \% \text { compared to the corresponding period in } \\
2018)\end{array}$} & \multicolumn{3}{|c|}{$\begin{array}{l}2432808,92(88.84 \% \text { compared to } \\
\text { the corresponding period in } 2019)\end{array}$} \\
\hline Export & 747309,34 & 641119,08 & 968241,28 & 466023,87 & 498870,66 & 335624,29 \\
\hline Import & 452059,51 & 470508,8 & 522320,77 & 378405,89 & 290756,8 & 239415,84 \\
\hline Indicator & April 2020 & May 2020 & June 2020 & July 2020 & Aug. 2020 & Sept. 2020 \\
\hline FTT & \multicolumn{3}{|c|}{$\begin{array}{c}3175325.91 \\
\text { (111.1\% compared to the corresponding period in } \\
2019)\end{array}$} & \multicolumn{3}{|c|}{ No data } \\
\hline Export & 478966,4 & 1059290 & 520365,71 & 415495 & No data & No data \\
\hline Import & 277564,38 & 806160,5 & 313578,62 & 362413 & No data & No data \\
\hline
\end{tabular}

*Compiled according to Ural Customs Administration [16].

According to customs statistics, in the 4th quarter of 2019, non-CIS countries accounted for $82.2 \%$ of the total value of foreign trade turnover (FTT) in the region, and the CIS countries $-17.8 \%$. Imports accounted for $38.8 \%$ of the turnover, exports $-61.2 \%$. Compared to the corresponding period in 2018, the value volume of the FTT increased by $6.6 \%$, the weight volume - by $27.2 \%$, the number of exporting countries decreased by $5.2 \%$, and the number of importing countries increased by $10.2 \%$. The share of the value of foreign trade turnover with non-CIS countries decreased by $3.7 \%$, and with the CIS countries increased by $3.7 \%$, respectively.

In the first quarter of 2020, non-CIS countries accounted for $77.8 \%$ of the total value of the region's FTT, while the CIS countries accounted for $22.2 \%$. Imports accounted for $42.7 \%$ of the turnover, while exports accounted for $57.3 \%$. In comparison with the corresponding period of 2019, the value volume of foreign trade turnover decreased by $11.1 \%$, weight - by $14.4 \%$, the number of exporting countries decreased by $17.4 \%$, the number of importing countries increased by $9.2 \%$. The share of the value volume of foreign trade turnover with non-CIS countries has not changed. It should be understood that in the first quarter of 2020, Sverdlovsk enterprises continued to fulfill their obligations under previously concluded international contracts.

The second quarter of 2020 is characterized by a decrease in foreign trade turnover with the CIS countries by $29.2 \%$ compared to the second quarter of 2019 and an increase with non-CIS countries by $23.0 \%$, as a result of which the positive balance of foreign trade for this period increased by $25.6 \%$ compared to the corresponding period in 2019 . In general, in 2020, the decrease in the FTT with the CIS countries was due to a decrease in exports to the Republic of Belarus by $8.5 \%$, to Kazakhstan by $2.9 \%$, to Uzbekistan by $11.8 \%$ and imports from Kazakhstan by $22.4 \%$, although the volume of imports from the Republic of Belarus increased by $34.8 \%$. In turn, the reduction of foreign trade turnover with non-CIS countries due to the decline in exports in Algeria by $90.9 \%$, to China by $14.6 \%$, in the Netherlands by $59.1 \%$, in Egypt by $97.6 \%$ in the US by $1.8 \%$ and imports from China by $8.8 \%$, from
Italy by $31.1 \%$, from Japan by $46.5 \%$, South Africa by $56.5 \%$.

The table shows that the pandemic of the new coronavirus infection (2019-nCoV) has had a negative impact on the development of the region's FTT. The closure of borders and the introduction of restrictive measures led to a sharp reduction in exports and imports by 2-3 times. However, in May 2020, the authorities managed to stabilize the situation and return relatively approximate indicators of dynamics by the summer.

In the commodity structure of exports of Sverdlovsk Oblast, as in 2019, metals and products made of them predominate $-67.7 \%$ (a decrease by $13.0 \%$ compared to the corresponding indicator in 2019), machinery, equipment and vehicles $-13.3 \%$ (an increase by $3.1 \%$ ), chemical industry products and rubber $-8.5 \%$ (a decrease by $15.3 \%)$, etc.

Structure of imports of Sverdlovsk Oblast in 2020, as in the previous year, is represented by metals and products made of them - $31.4 \%$ (an increase by $35.0 \%$ compared with the corresponding period in 2019), machinery, equipment and vehicles - 31.3\% (an increase by $37.4 \%$ ), mineral products $-13.9 \%$ (a decrease by $29.3 \%$ ), chemical products and rubber $-12.3 \%$ (a decrease by $26.8 \%$ ), food products and raw materials for their production - $4.3 \%$ (an increase by $13.2 \%$ ).

Significant changes in the structures of exports and imports of the region have not been identified.

\section{DISCUSSION OF THE RESULTS}

The main result that was obtained by analyzing the dynamics of indicators that characterize foreign trade of Sverdlovsk Oblast is that in the near future, the trend of reducing exports and imports will stabilize at the reduced FTT indicators without further significant reduction, which is likely to be influenced by a number of factors:

1. Online negotiations are less effective in comparison with face-to-face meetings on international cooperation with most countries in South-East Asia and Europe, as a result, in the second quarter of 2020, Sverdlovsk foreign trade entities did not have the opportunity to meet in 
person with foreign colleagues and potential partners, which gives reason to assume a sharp decrease in the number of new international contracts concluded for execution. It is necessary to understand the prolonged nature of this situation in the event of further extension of restrictive measures in the world.

2. The world recorded a decline in the global and national economies, which indicates a decrease in the purchasing power of international trade entities.

3. A number of countries, such as the United States, Germany, France, Italy and many others, have made a statement in the world community about getting down to import substitution. The countries are already actively implementing measures aimed at supporting domestic producers in key areas and industries.

4. The products exported by Sverdlovsk producers are particularly competitive in terms of optimal and affordable pricing policy, which is why foreign partners will not be able to abandon them completely, ensuring the minimum possible export of local products. Also, the exchange rate plays an increasing role here, especially the devaluation of the ruble.

In general, in 2020-2021 Sverdlovsk Oblast's foreign trade is expected to decline by $25-30 \%$. The Ministries of Economic Development of the Russian Federation and of Foreign Affairs forecast this figure at $30 \%$, and the World Trade Organization - up to $32 \%$

\section{CONCLUSION}

At present, it seems that new approaches and views are needed on the process of forecasting and determining trends in the consequences of the spread of the coronavirus pandemic. On the one hand, these approaches should primarily reflect the level of well-being of the population, the so-called happiness index, and on the other hand, they should be based on objective statistical data. Since exports and imports are not only the basis of international economic relations, but also indicators related indirectly and directly to the well-being of the population, it seems that the analysis of the consequences of the spread of the coronavirus pandemic should be based on the dynamics of indicators that characterize the subject's foreign trade

\section{REFERENCES}

[1] Albu, L. L., Preda, C. I., Lupu, R, Dobrota, C. E.; Calin, G. M.; Boghicevici, C. M. (2020), "Estimates of dynamics of the Covid-19 pandemic and of its impact on the economy", Romanian Journal of Economic Forecasting, Vol. 22 No. 2, pp. 5-17.

[2] Ceylan, R. F., Ozkan, B., Mulazimogullari, E. (August 2020), "Historical evidence for economic effects of COVID-19", The European Journal of Health Economics, Springer;
DeutscheGesellschaftfürGesundheitsökonomie (DGGÖ), Vol. 21(6), pp. 817-823.

[3] Erokhin, V; Gao, T. M. (2020), "Impacts of COVID-19 on Trade and Economic Aspects of Food Security: Evidence from 45 Developing Countries", International Journal of Environmental Research and Public Health, Vol. 17 No. 16, Article number: 5775.

[4] Malliet, P; Reynes, F; Landa, G; Hamdi-Cherif, M; Saussay, A. (2020), “Assessing Short-Term and LongTerm Economic and Environmental Effects of the COVID-19 Crisis in France", Environmental and Resource Economics, Vol. 76 No. 4 pp. 867-883.

[5] Petrunenko, I.; Podtserkovny, I., "Transformation of the strategy of state economic policy in modern conditions", Baltic Journal of Economic Studies, Vol.6 No. 3, pp. 107-113.

[6] Phillipson, J ; Gorton, M; Turner, R; Shucksmith, M; Aitken-McDermott, K. "The COVID-19 Pandemic and Its Implications for Rural Economies", SUSTAINABILITY, Vol.12 No. 10, Article number: 3973.

[7] Rastvortseva, S. N; Snitko, L. T. "Regional Specialization and Agglomeration Effects in the Russian Economy", Economic and Social Changes: Facts, Trends, Forecast, Vol.13, No. 3, pp. 46-58.

[8] Singh, G; Dharampal, Jyoti, "Economic Impact of COVID-19 Pandemic: Who are the Big Sufferers?", Indian Journal of Economics and Development, Vol.16 No. 2, pp. 320-326.

[9] Bondarenko, A. (2020) "Neural network calculated" ["Neyroset podschitala"], Rossiyskaya gazeta - Ekonomika Dalnego Vostoka, No. 161(8215).

[10] Bocharnikova, E. V., Avdyukova, A. E. (2019), "International relations of Sverdlovsk Oblast: foreign economic aspect" ["Mezhdunarodniye svyazi Sverdlovskoy oblasti: vneshneekonomicheskiy aspect"], Vestnik sotsialno-gumanitarnogo obrazovaniya i nauki, No. 1. pp. 40-46.

[11] Gnatyshina, E. V., Sidelnikova, T. V. (2016), "Russian happiness index" ["Rossiyskiy indeks schastya"], Mezhdunarodniy nauchno-issledovatelskiy zhurnal, No. 8 (50) Part 1, pp.25 - 28.

[12] Lebedin, N. Yu. (2017), "Economic welfare and the problem of its provision in modern Russia" ["Ekonomicheskoye blagopoluchiye i problema yego 
obespecheniya v sovremennoy Rossii"'], Problemy sovremennoy ekonomiki, No. 3 (63), pp. 46-48.

[13] World Trade Organization, "The COVID-19 pandemic and trade-related developments in LDCs".

[14] RBC, Moscow marketing.rbc.ru (2020),

"Consequences of the COVID-19 pandemic for the Russian economy: survey of business representatives".

[15] Food and Agriculture Organization of the United Nations, "The new coronavirus (COVID-19)".

[16] Ural Customs Administration, available at: http://www.utu.customs.ru/folder/146563(accessed 29 September, 2020). 